\title{
KURANGNYA DUKUNGAN MODAL MENJADI SALAH SATU FAKTOR LAMBATNYA PENGEMBANGAN AMAL USAHA KESEHATAN PERSYARIKATAN MUHAMMADIYAH (Studi Kasus di Kota Pekanbaru)
}

\author{
Juli Widiyanto, Bakaruddin, Wafi Nur Muslihatun
}

\author{
Universitas Muhammadiyah Riau \\ Poltekkes Kemenkes Jogjakarta \\ Jl. Tuanku Tambusai Ujung, Pekanbaru 28291, Riau \\ $e$-mail : juliwidiyanto@umri.ac.id
}

\begin{abstract}
ABSTRAK
Latar Belakang : Fasilitas kesehatan merupakan bagian yang tidak dapat terpisahkan sebagaimana konsep paradigma sehat dalam rangka terwujudnya derajad kesehatan masyarakat yang setinggi-tingginya, terutama fasilitas kesehatan berupa rumah sakit, rumah bersalin, dan klinik sebagai wadah bagi seluruh lapisan masyarakat yang membutuhkan layanan kesehatan. Persyarikatan muhammadiyah adalah salah satu organisasi yang cukup berperan besar terhadap dinamika kehidupan masyarakat terutama riau, sekalipun telah banyak amal usaha yang telah dirintis oleh muhammadiyah namun amal usaha kesehatan peryarikatan di riau dapat diaktegorikan lambat, karena sampai saat ini persyarikatan baru memiliki klinik yang terbatas bahkan rumah sakit belum mampu untuk didirikan, banyak faktor yang menyebabkan lambatnya pengembangan amal usaha salah satunya adalah kurangnya dukungan modal. Tujuan Penenlitian : Penenlitian ini bertujuan untuk menganalisis faktor kurangnya dukungan modal berpengaruh terhadap pengembangan amal usaha kesehatan persyarikatan muhammadiyah.

Metode Penelitian: Penenlitian ini merupakan peenlitian analaitik observasional dengan rancangan cross sectional study. Teknik sampling yang digunakan adalah sampling jenuh, analisis digunakan dengan uji person Chi-Square.

Hasil Penenlitian : hasil penenlitian ini membuktikan bahwa dukungan modal berpengaruh terhadap pengambangan amal usaha kesehatan peryarikatan muhammadiyah, hal tersebut dibuktikan dengan nilai $\mathrm{p}$-value < 0,05 yaitu 0,046 dan Odd Ratio : 3,3 dengan Confiden Interval : 1,88-13,1

Simpulan : Simpulan pada penenlitian ini adalah kurang dukungan modal berpengaruh terhadap lambatnya pengembangan amal usaha kesehatan persyarikatan muhammadiyah
\end{abstract}

Kata Kunci : Dukungan Modal, Amal Usaha Kesehatan, Persyarikatan

\section{PENDAHULUAN}

Isu globalisasi merupakan fenomena modern, ditandai dengan perilaku interdependence, dan overlapping di banyak sektor hal tersebut memberikan dampak perubahan cepat, pada seluruh dunia baik negara maju maupun berkembang. Kecenderungan ini berpengaruh tidak terbatas pada bidang umum, tetapi dalam bidang kesehatanpun terjadi perubahan yang cukup signifikan antara lain perkembangan rumah sakit dari hospital yang konvensional berubah menjadi e-hospital, dan berubah menjadi u-hospital dan kemudian menjadi intelligent hospital. Perkembangan pelayanan kearah travel medicine atau health tourism, kemudian tekanan yang tidak disangka-sangka dari banyak penjuru, antara lain dari peningkatan permintaan dalam bidang pelayanan kesehatan, tumbuhnya tekanan lingkungan dan menurunnya ekonomi pelayanan kesehatan (Anonym,1997).

Kesehatan merupakan bagian yang tidak terpisahkan dari daur hidup manusia yang tidak terlepas dari sehat sakit sebagaimana tergambar dari paradigm sehat sakit. Untuk mewujudkan derajat kesehatan yang setinggi-tingginya bagi masyarakat, diselenggarakan upaya kesehatan yang terpadu dan menyeluruh dalam bentuk upaya kesehatan perseorangan dan upaya kesehatan masyarakat. Upaya kesehatan diselenggarakan dalam bentuk kegiatan 
dengan pendekatan promotif, preventif, kuratif, dan rehabilitatif yang dilaksanakan secara terpadu, menyeluruh, dan berkesinambungan (Undang-undang kesehatan no 36 tahun 2009)

Dalam rangka mewujudkan tujuan kesehatan dan mengatasi berbagai masalah kesehatan yang muncul tersebut perlu penanganan secara komprehensif dan keterlibatan semua lapisan masyarakat baik pemerintah, swasta, perorangan maupun organisasi. Organisasi yang punya komitmen untuk membantu pemerintah dalam mewujudkan indosesia sehat adalah persyarikatan muhammadiyah. Berdasarkan data litbangkes bahwa hampir diseluruh wilayah Indonesia muhammadiyah memiliki amal usaha berbasiskan kesehatan seperti rumah sakit, atau Pembina kesejahteraan Umat (PKU), klinik maupun rumah bersalin. Namun perkembangan fasilitas kesehatan tersebut tidak merata pada semua daerah temasuk provinsi riau (KMM, 2005).

Pelayanan kesehatan yang sudah dibangun dan didirikan oleh persyarikatan Muhammadiyah relative sudah cukup banyak, sehingga sudah selayaknya Muhammadiyah memiliki sistem pelayanan kesehatan Muhammadiyah. Sistem Pelayanan Kesehatan terdiri dari struktur dan fungsi, untuk struktur tediri dari unsur pembentuk struktur, sedang fungsi adalah unsur pembentuk fungsi.

Pemerataan pusat layanan kesehatan sebagai salah satu amal usaha seperti Rumah sakit dan klinik di provinsi riau masih cenderung belum berkembang, hasil survey di kota pekanbaru menunjukan bahwa berbagai pusat kesehatan sudah bermunculan terutama Rumah Sakit swasta, baik rumah sakit khusus maupun rumah sakit tipe $\mathrm{C}$ dan $\mathrm{D}$ dan bahkan ada satu manajemen rumah sakit swasta yang telah memiliki cabang sebanyak 3 rumah sakit di kota pekanbaru. Sedangkan rumah sakit persyarikatan muhammadiyah yang memiliki warga persyarikatan cukup besar belum juga memiliki fasilitas kesehatan yang memadai yang dapat dimanfaatkan oleh warga persyarikatan.

Rumah sakit adalah institusi yang padat modal, padat karya, padat biaya, padat teknologi, padat resiko, padat kompetensi dan padat pahala, oleh karena itu pasti menjadi padat data dan padat informasi. Pasien yang menjadi pusat objek pelayanan kesehatan merupakan sumber data, sumber informasi, sumber pengetahuan, sumber penyakit, sumber dana, sumber masalah juga sumber pahala. Rumah sakit merupan sumber pelayanan yang paling komprehensif dari seluruh bentuk dan jenis pelayanan kesehatan (Azhar, 2005).

Hasil survey dan kondisi riil di provinsi riau khususnya kota pekanbaru, sejak berdirinya persyarikatan muhammadiyah sampai sekarang belum memiliki rumah sakit sebagai pusat rujukan bagi warga persyarikatan. Pada hakekatnya banyak faktor yang menyebabkan lambatnya pengembangan amal usaha peryarikatan muhammadiyah dan faktor rendahnya dukungan modal merupakan salah satu faktor penyebab terutama di kota pekanbaru.

\section{METODOLOGI PENELITIAN}

Penenlitian ini merupakan penenlitian analitik observasional, desain yang digunakan pada penenlitian ini adalah cross sectional Study yaitu sebuah rancangan penelitian yang pengukuran atau pengamatannya di lakukan dengan cara bersama-sama antara pengambilan 
data dan hasil pengukuran pada dua variabel penelitian.

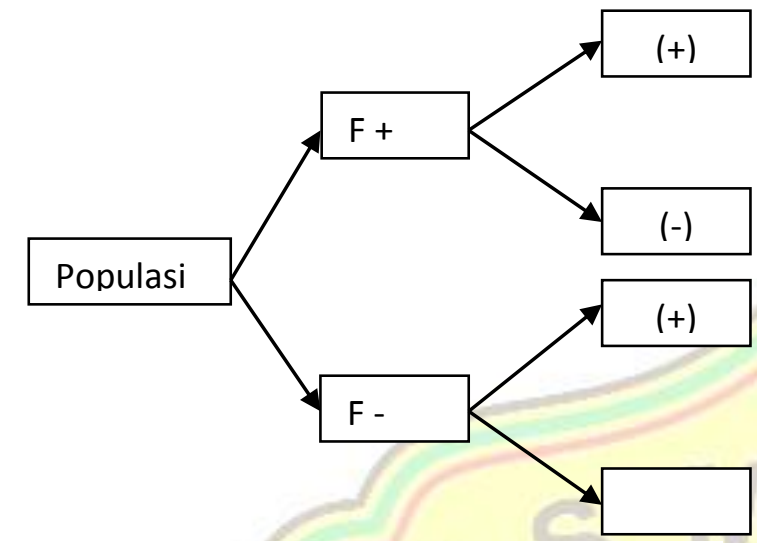

Gambar 1. Sekema Diagram Cross Sectional Study

Variabel yang diukur dan diamati pada penenlitian ini adalah variabel dukungan modal (didukung dan tidak didukung) dan variabel lambatnya pengembangan amal usaha (Lambat dan tidak lambat).

Analisis data pada penelitian ini dilakukan menggunakan alat bantu komputer dengan program SPSS for windows release 17.0 dengan tahapan analisis sebagai berikut: Analisis univariat dilakukan dengan cara membuat distribusi frekuensi dari setiap variabel, hasil analisis ini disajikan dalam bentuk table dan diagram serta narasi yang meliputi karakteristik responden dan data penunjang lain. Analisis bivariat dilakukan untuk menguji hubungan antara dua variabel yaitu masing-masing variabel bebas dengan variabel terikat. Uji statistik yang akan digunakan adalah uji chi square dengan menghitung signifikansi. Tingkat kepercayaan ditentukan $p=0,05$ dengan confident interval 95\%. Persamaan pengaruh dapat terlihat seperti dibaah ini:

$$
r=\frac{n \sum x y-\sum x \sum y}{\sqrt{\left[n \sum x^{2}-\left(\sum x\right)^{2}\right]\left[n \sum y^{2}-\left(\sum y\right)^{2}\right]}}
$$

Selanjutnya juga diperoleh nilai besar risiko (Odds Ratio/OR) paparan terhadap kasus dengan menggunakan table $2 \times 2$ sebagai berikut :

Tabel 1. Kontingensi

\begin{tabular}{ccccc}
\hline No & $\begin{array}{c}\text { Variabel } \\
\text { Dependen }\end{array}$ & \multicolumn{2}{c}{$\begin{array}{c}\text { Variabel } \\
\text { Independen }\end{array}$} & Total \\
\cline { 3 - 4 } & & Ya & Tidak & \\
\hline 1 & $(+)$ & $\mathrm{a}$ & $\mathrm{b}$ & $\mathrm{a}+\mathrm{b}$ \\
2 & $(-)$ & $\mathrm{c}$ & $\mathrm{d}$ & $\mathrm{c}+\mathrm{d}$ \\
\hline & Total & $\mathrm{a}+\mathrm{c}$ & $\mathrm{b}+\mathrm{d}$ & $\mathrm{a}+\mathrm{b}+\mathrm{c}+\mathrm{d}$ \\
\hline
\end{tabular}

\section{HASIL DAN DISKUSI}

a. Analisis Univariat

Tabel 2. Distribusi Umur Responden

\begin{tabular}{lcccc}
\hline Variabel & Mean & SD & Min - Max & $95 \%$ CI \\
& & & & \\
\hline Umur & 56,45 & 9,007 & $41-70$ & $52,68-$ \\
& & & & 60,01 \\
\hline
\end{tabular}

Hasil analisis didapatkan rata-rata umur responden adalah 56,45 tahun (95\% CI: 52,68 - 60,01), dengan standar deviasi 9,007 tahun. Umur termuda 41 tahun dan umur tertua 70 tahun. Dari hasil estimasi interval dapat disimpulkan bahwa 95\% diyakini bahwa ratarata umur responden adalah diantara 52,68 sampai dengan 60,01 tahun

Tabel 3. Distribusi frekuensi Pekerjaan dan Pendidikan

\begin{tabular}{lll}
\hline Variabel & F & $\%$ \\
\hline Pekerjaan: & & \\
PNS & 9 & 34,6 \\
Pegawai Swasta & 6 & 23,1 \\
Wiraswasta & 7 & 26,9 \\
Lain-lain & 4 & 15,4 \\
\hline Pendidikan : & & \\
Sarjana (S1) & 7 & 26,9 \\
Master (S2) & 12 & 46,2 \\
Doktor (S3) & 7 & 26,9 \\
\hline
\end{tabular}

Hasil analisis menunjukan bahwa mayoritas pekerjaan responden adalah pegawai swasta Sipil (PNS) yaitu 9 (34,6\%), dan pendidikan mayoritas berpendidikan master yaitu 12 $(46,2 \%)$. 
b. Analisis Bivariat

\begin{tabular}{|c|c|c|c|c|c|c|c|}
\hline \multirow{3}{*}{ Dukungan Modal } & \multicolumn{4}{|c|}{$\begin{array}{l}\text { Pengembangan Amal usaha } \\
\text { kesehatan Persyarikatan }\end{array}$} & \multirow{3}{*}{ OR } & \multirow{3}{*}{ (CI 95\%) } & \multirow[t]{3}{*}{$\begin{array}{l}\text { p- } \\
\text { Value }\end{array}$} \\
\hline & \multicolumn{2}{|c|}{ Lambat } & \multicolumn{2}{|c|}{ Sangat Lambat } & & & \\
\hline & $\mathrm{n}$ & $\%$ & & $\%$ & & & \\
\hline Di Dukung & 4 & 36,3 & 11 & 73,3 & 3,3 & 1,88 & 0,046 \\
\hline Kurang Didukung & & 63,7 & 4 & 26,7 & & 15 & \\
\hline Total & 11 & 100 & 15 & 100 & 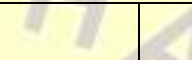 & & \\
\hline
\end{tabular}

Hasil analisis pengaruh dukungan modal terhadap lambatnya pengembangan amal usaha kesehatan diperoleh bahwa ada sebanyak 7 $(63,7 \%)$ kurangnya dukungan modal mempengaruhi lambatnya pengembangan amal usaha kesehatan. Sedangkan kurangnya dukungan modal mempengaruhi sangat lambatnya pengembangan amal usaha kesehatan $11(73,3 \%)$. Hasil uji statistik diperoleh nilai $\mathrm{p}=0,049$ maka dapat disimpulkan ada pengaruh yang signifikan antara lambatnya pengembangan amal usaha dengan rendahnya dukungan modal dalampendirian amal usaha kesehatan. Dari hasil analisis diperoleh pula nilai $\mathrm{OR}=3,3$, artinya kurangnya dukungan modal mempunyai peluang 3,3 kali untuk berpengaruh terhadap lambatnya pengembangan amal usaha kesehatan.

Modal dapat diinterpretasikan sebagai sejumlah uang yang digunakan dalam menjalankan kegiatan-kegiatan bisnis, banyak kalangan yang memandang bahwa modal uang bukanlah segala-galanya dalam sebuah bisnis. Namun perlu dipahami bahwa uang dalam sebuah usaha sangat diperlukan. \& Utari, 2014). Modal usaha juga berkaitan dan erat hubungannya dengan tingkat perputaran dan modal kerja dan struktur modal
Yang menjadi persoalan di sini bukanlah penting tidaknya modal, karena keberadaannya memang sangat diperlukan, akan tetapi bagaimana mengelola modal secara optimal sehingga bisnis yang dijalankan dapat berjalan lancar (Amirullah, 2005).

Dalam arti kata bahwa modal memiliki peranan yang sangat signifikan terhadap perkembangan suatu usaha baik yang berorientasi pada materi atau laba maupun yang berorientasi pada jasa seperti rumah sakit dan klinik. Meurut Endang Purwati (2012) Modal usaha terbukti berpengaruh positif dan signifikan terhadap perkembangan usaha, hal ini perlu mendapat perhatian dikarenakan hasil penelitian menunjukan bahwa modal usaha mempunyai pengaruh yang paling dominan, UMKM memerlukan kemudahan untuk medapatkan modal. Demikian semakin besar konsumsi modal yang dikeluarkan akan berimbas pada pendapatan suatu usaha, artinya bahwa jika diaktkan dengan pendirian suatu amal usaha maka besarnya modal yang dikeluarkan maka akan berkolerasi terhadap realisasi tujuan amal usaha (Dewi

karena akan berpengaruh terhadap profitabilitas suatu usaha. 


\section{KESIMPULAN}

Berdasarkan hasil analisis maka dapat disimpulkan bahwa dukungan modal berpengaruh terhadap perkembangan suatu amal usaha persyarikatan sehingga berhubungan dengan lambatnya pendirian amal usaha persyarikatan. Sehingga dapat disarankan kepada peryarikatan agar dapat membuat jejaring yang terintegrasi disemua komponen dan lapisan warga persyarikatan termasuk simpatisan persyarikatan dalam penggalangan dana untuk dapat mewujudkan cita-cita persyarikatan yaitu menumbuh kembangkan amal usaha kesehatan persyarikatan terutama klinik dan rumah sakit di provinsi riau.

\section{DAFTAR PUSTAKA}

Azlina, N. (2012). Pengaruh tingkat perputaran modal kerja, struktur modal dan skala perusahaan terhadap profitabilitas. PEKBIS (Jurnal Pendidikan Ekonomi Dan Bisnis), 1(02).

Amirullah, dan Imam Hardjanto, (2005). Pengantar Bisnis, Edisi Pertama, Graha Ilmu, Yogyakarta.

Aminudin,M. Susanto. (2013). Analisis FaktorFaktor Yang Mempengaruhi Perilaku Pasien Dalam Memanfaatkan Rawat Inap Di Rumah Sakit Pku Muhammadiyah Nanggulan

Anonym. (1997), Profil \& Direktori Amal Usaha Muhammadiyah \& 'Aisyiyah Bidang Kesehatan, Jakarta, Pusat Data Minaco Adv.

Dewi, R. S. (2013). Pengaruh Faktor Modal Psikologis, Karakteristik Entrepreneur, Inovasi, Manajemen Sumber Daya Manusia, Dan Karakteristik UKM Terhadap Perkembangan Usaha Pedagang Di Pasar Tradisional (Studi Kasus Pada Pedagang Sembako Dan Snack Di Pasar Peterongan). Jurnal Administrasi Bisnis, 2(1).

Dewi, N. P. M., \& Utari, T. (2014). Pengaruh Modal, Tingkat Pendidikan dan Teknologi terhadap Pendapatan Usaha Mikro Kecil dan Menengah (UMKM) di Kawasan Imam Bonjol Denpasar Barat. E-Jurnal Ekonomi Pembangunan Universitas Udayana, 3(12).

Firdausa, R. A., \& Arianti, F. (2012). Pengaruh Modal Awal, Lama Usaha Dan Jam Kerja Terhadap Pendapatan Pedagang Kios Di Pasar Bintoro Demak (Doctoral dissertation, Fakultas Ekonomika dan Bisnis).

Ganitri, P. T., Suwendra, I. W., \& Yulianthini, N. N. (2015). Pengaruh Modal Sendiri, Modal Pinjaman, dan Volume Usaha terhadap Selisih Hasil Usaha (SHU) pada Koperasi Simpan Pinjam. Jurnal Jurusan Manajemen, 2(1).

Hermuningsih, S. (2014). Pengaruh profitabilitas, growth opportunity, struktur modal terhadap nilai perusahaan pada perusahaan publik di Indonesia. Buletin ekonomi moneter dan perbankan, 16(2), 127148.

Riswandani, Y. T. S. (2013). Pengaruh Fasilitas, Biaya, dan Promosi Terhadap Kepuasan Pasien Rawat Inap. Daya Saing Jurnal Ekonomi Sumber Daya, 14(2), 88-89.

Purwanti, E. (2013). Pengaruh karakteristik wirausaha, modal usaha, strategi pemasaran terhadap perkembangan UMKM di Desa Dayaan dan Kalilondo Salatiga. Jurnal Ilmiah Among Makarti, 5(9).

Thobias, E. (2013). Pengaruh modal sosial terhadap perilaku kewirausahaan (suatu studi pada pelaku usaha mikro kecil menengah di Kecamatan Kabaruan Kabupaten Kepulauan Talaud). Jurnal Acta Diurna, 2(2).

Undang-Undang Republik Indonesia Nomor 36 tahun 2009 Tentang Kesehatan

Winarko, S. P. (2014). Pengaruh Modal Sendiri, Jumlah Anggota Dan Aset Terhadap Sisa Hasil Usaha Pada Koperasi Di Kota Kediri. Nusantara of Research, 1(02). 